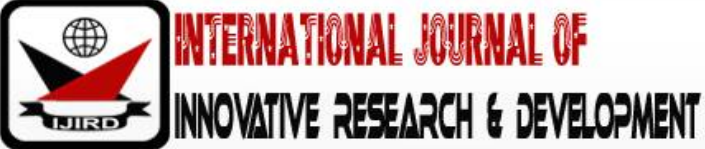

ISSN 2278 - 0211 (Online)

\section{Analytical Study between Flat and Hollow Block Slabs in Sudan}

\author{
Dr. Ali Hussein Mohamed Ali \\ Assistant Professor, Department of Civil Engineering, College of Engineering \& Architecture, \\ University of Bahri, Sudan \\ Sheikh Abdulkhaleq Sheikh Thabit \\ M.Sc. Student, Department of Civil Engineering, College of Engineering \& Architecture, \\ University of Bahri, Sudan
}

\begin{abstract}
:
In this study, one of a structural member which called slabs are studied as general and in particular, one of these types hollow block and flat slab are investigated as a structural system. These structural systems are methods of construction for flooring system which are used in Sudan, and this research is covering the analysis and design of hollow block and flat slab using Safe program according to British code (BS 8110-1997). The results of analysis and design are compared together to find the best system and cost-effectiveness. The methodology comprises of the method and the design that was used to conduct the case studied and explain the way of analysis and design of hollow block and flat slab for a residential building in Sudan. There were two models with variable plan areas $(13 \mathrm{~m} \times 23 \mathrm{~m})$ and $(14 \mathrm{~m} \times 23 \mathrm{~m})$ analyzed and designed according to British code 8110. The result obtained from the study shows that the hollow block slab has a lightweight and zero punching shear making it more preferable choice for residential building. Considering from the economical point of view it is less expensive than that of the flat slab using hollow concrete block; hence the total quantity of steel reinforcement and concrete used is less. In model 1 for the cost of materials and the total cost increased for the flat slab is (27.31\% - 21.54\%) and on other hand In model 2 for the cost of materials and the total cost increased for the flat slab is (35.63\% - 29.17\%).To conclude, hollow block slab is the best alternative method in frame structures due to its capability to reduce the self-weight of the slab then the cost especially in long spans and have a good overall behavior in hot countries like Sudan.
\end{abstract}

Keywords: Hollow block slab, flat slab, analysis and design, Safe software, British code (BS 8110-1997)

\section{Introduction}

Slabs are the structural elements that convey the additional dead and imposed loads in different structures. They are used in buildings, paths, and bridges. Usually, they can be classified to one way and two ways systems. One way slabs with beams used are commonly for small spans not exceed six meters in one direction. Two-way slabs with beams and without beams are used for longer spans. Two- way slab systems are fundamentally used when there are long spans to reduce the slab thickness and to decrease the internal forces and the slab deflection (Ibrahim Mohammad Arman, 2014). Flat slab structures are used ultimately which have economical and functional advantages of the structural system and the architectural flexibility. The behavior and design of flat slab structures for gravity loads are well created. Their behavior under lateral displacements, however, is not well understood and lateral design methods are not well created (Laurel M. Dovich and James K. Wight; 2005).

Hollow block slab is designed to reduce a dead load of the slab and to facilitate formwork. It is a common and significant type of voided slab used in large span floor system. The portions of the slab thickness are full by the hollow blocks; this will conduct to give a deeper arm for the reinforcement while saving concrete and hence decreasing slab selfweight. The ribs reinforcement bars in the slab are located between the blocks. The blocks that used in slabs may be Styrofoam or concrete blocks. (Adel A. Al-Azzawi, Abbas J and Al-Asdi; 2017).

\subsection{Problem Statement}

Due to the different types of concrete slabs systems, it is necessary to determine the appropriate type of structure, whether residential, commercial, or otherwise, to give architectural and structural flexibility and economically. In this research, we could study the difference between hollow block slab and flat slab, as well as, which slab is more economical and suitable to applied in Sudan.

\subsection{Research Questions and Hypothesis}

- What type of slab is economical? 
- How to calculate the design parameters of the hollow block and flat slab according to British standard code?

- What is the suitable program for analysis and design the both slabs.

- What are the major differences between the two slabs?

\section{Literature Review}

(Bikçe and Akyol, 2017) have studied ten buildings with up to 16 floors, five of those buildings with solid slabs and the other with lightweight hollow block slabs, which have been designed in accordance with updated earthquake regulations. As a result of the study, it has been determined that the cost difference varies between 1.33 and $15 \cdot 37 \%$ when one slab various replaced with the other.(Al-Azzawi and Abed 2017) have studied experimentally the behavior of reinforced concrete slabs with hollow cores under varying study parameters. The experimental part covered testing 8 slab samples of hollow-core and solid models with $(2.05 \mathrm{~m})$ length, $(0.6 \mathrm{~m})$ width, and $(25 \mathrm{~cm})$ thickness under two monotonic line loads.(NavjotKaur Bhatia, June 2016) have examined the dynamic behavior of the flat slab and grid slab in comparison to the conventional slab. In the study of the project the writer performs the dynamic analysis for seismic and wind forces of multistory RC building with different plans like square, orthogonal hexagonal, orthogonal for the flat slab, grid slab, and conventional slab. The above have analyzed for different stories like 10,20, and 30 and also for the different earthquake zone according to the Indian standard code of practice $(1893$ - 2002). They made the relation between earthquake responses and strengths. It is detected from the study that the behavior and structural behavior of flat slab and grid slab is preferable in comparison to a conventional slab. It is shown in term of deflection and cost of the material. (Salman I. Khan and Ashok R. Mundhada 2015) have conducted a comparative study between flat and grid slab on Reinforced cement concrete buildings. The dynamic analysis method is response spectrum using Etabs software for three buildings having different high rise $(12.15,18)$ stories the study can represent that flat slab has lower performance than the grid slab based upon flat slab has $4 \%$ more base shear and lateral displacement additional to flat slab has significantly more story drift. (Makode R K and Akhtar 2014) have compared the seismic response of multistoried structures (12-story building) with flat and grid slabs using the response spectrum method, the study concludes that at the columns in the center of the plan was less in grid slab as compared to the building with the flat slab, moreover, at each storey the building with grid performed less storey drift than flat slab.(Allawi 2014) have carried out experimental tests on the one-way voided slab to investigate the structural behavior of the reinforced concrete slabs containing cavities. (Rahman, Vakas K., and A. R. Mundhada'2013) have worked on the design of reinforced cement concrete in addition to pre-stressed concrete flat slabs for different spans and then compare the results Programming in Microsoft Excel is done to design both types of flat slabs. . The idea is to reach a definite conclusion regarding which one of the two techniques is more suitable for another. Results reveal that a pre-stressed concrete flat slab is more expensive than reinforced cement concrete flat slab for smaller spans but for longer span pre-stressed concrete flat slab is more economic. (Alzanen, A.H.M, 2012) have included the analysis and design of hollow block slab according to different provisions codes: Egyptian cod (EPC 203-2007), American code (ACI 318-2005), and British code (BS 8110-1997).In addition to reinforcement detailing and construction method. The results of analysis and design by codes are compared to find the code designable achieving economical and safety.

The economical and safety code is used to analyze and design two floors system manually; flat and hollow block slab and compare results to reach a definite conclusion regarding the superiority of the two-floor systems over one another. There are other features that make it a suitable structural system for hot places like Sudan. (Amit A. Sathwane2011) have investigated that the among flat slab, grid slab, and flat slab with the drop which is economical for the nexus point opposite+e to vidhanbhavan and beside the NMC office. The analysis of flat slab, grid slab, and flat slab without drop done both manually using STAAD PRO V8i software according to IS 456-2000. It is conducted in this study that a flat slab with a drop is economical compare to other considered slab for the nexus point. It has also appeared in the study that concrete required for the flat slab with and without drop is less than the grid slab and steel required for the flat slab with drop and grid slab is less than the flat slab without a drop. (Ghoneim and El-Mihilmy, 2008)Other advantages include reduction of loads on the foundation thereby allowing more storeies to be built on the same foundation, low reinforcement per square meter and high acoustic and thermal insulation. Hollow block floors proved economic for spans of more than $5 \mathrm{~m}$ with light or moderate live loads, such as hospitals, office, or residential buildings. They are not suitable for structures having heavy live loads such as warehouses or parking.

\section{Research Methodology}

The design method which used in this study is the Finite elements [Safe program]. In conventional structural analysis, numerous approximations are introduced and the engineer is normally content to accept the resulting facilitation. Actual elements are considered as idealized one-dimensional linear members; deformations due to axial force and shear are assumed to be adequately small to be neglected; and so on. In general, such assumptions are valid and the results of the analysis are adequately close to the values that would occur in the actual structure to be acceptable.

The finite element is that a body or continuum is divided into smaller elements of finite dimensions called finite elements connected at a lot of joints called nodal points or nodes. The displacements of these nodal points will be the basic unknown parameters of the problem. The original body or structure is then idealized as an assemblage of these elements connected at nodal points. In the most popular procedure, a simple displacement purpose at the specified nodal points of elements is assumed in terms of the displacements at the prescribed nodal points of elements (Kai, Cheung Yau, and Olgierd Cecil Zienkiewicz 1967).

Programs that work on the analysis and design of high buildings contributed to save time and effort and high accuracy in the results. These programs work on the system of finite elements, where the origin is divided into small elements in the form of a network and examples of these programs are (Sap, Safe, Etabs, Staadprog). It is worth 
mentioning that the elements for columns, beams, and ties are known in these programs as frame elements, and those for slabs, shear walls, and ramps as shell elements [Tayseer Ismail Hasb ALLA 2018].

\subsection{Safe Program}

Safe is a sophisticated, yet easy to use, special purpose analysis, design, and detailing program developed especially for the concrete slab and base mat systems. Safe version-2016 couples powerful object-based modeling tools with an intuitive graphical interface, allowing the efficient and quick modeling of slabs of arbitrary or regular geometry with post-tensioning, drop panels, openings, edge beams, ribs, and slip joints, supported by columns, walls, or soil. Design is seamlessly integrated with the modeling and analysis, and provides extensively reporting of the required rebar calculated based on a chosen design code. Detailed drawings may be produced easily for slabs and beams designed using Safe. Safe may be used as a stand-alone application, or may be used in connection with Etabs to complete analysis, design, and detailing of concrete floor plates.

Safe offers the widest group of analysis and design tools available for the structural engineer working on concrete slabs. The list exemplifies just a part of the varieties of systems and analyses that Safe can easily handle slabs as following:

- Flat slabs.

- Waffle slabs.

- Ribbed slabs.

- Rectangular or circular slabs.

- Slabs subjected to any number of vertical load patterns and combinations.

- Slab reinforcement calculated based on user-defined design strips.

User controlled placement of slab rebar.

- Punching shear checks and punching reinforcement design.

- Dynamic analysis of floor systems and foundations by exporting response spectrum analysis results from Etabs to Safe.

- $\quad$ Reinforcement contours calculated using Finite Element forces.

\subsection{Scope of Case Study}

The scope of the work consists of the design and detailing of floor slab for a single storey office Block for the two cases considered (flat slab and hollow block slab). A Bill of quantities was prepared based on a typical design and detailing of structural members of the two cases considered. The design model consists of a single storey office block with a plan consisting of plan areas of $(23 \mathrm{~m} \times 13 \mathrm{~m})$ and $(23 \mathrm{~m} \times 14 \mathrm{~m})$ as follows in Figures (3.1) and (3.2).

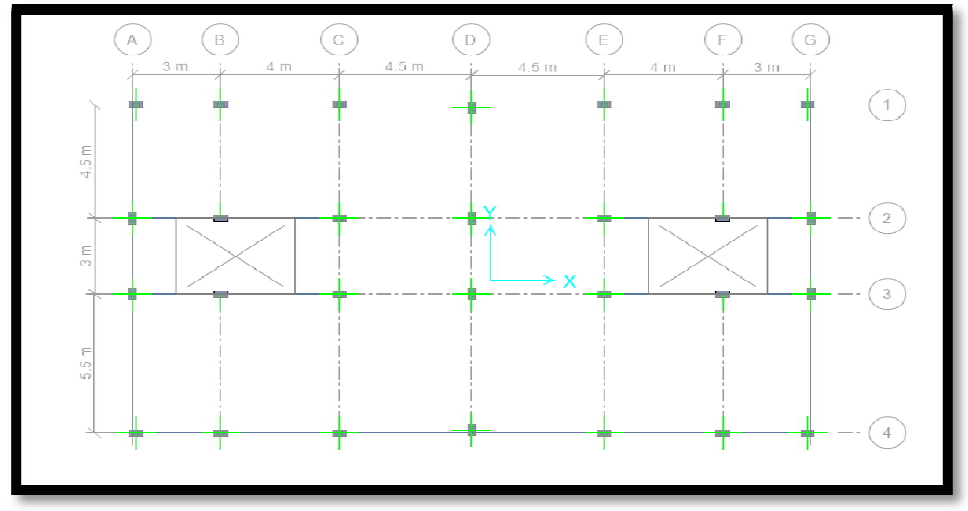

Figure 1: Layout of Plan [1]

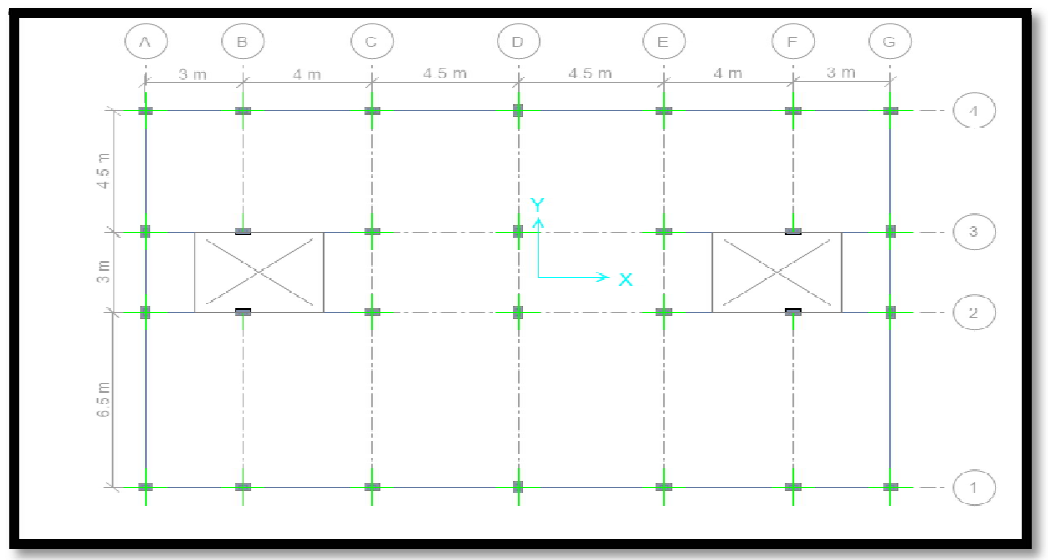

Figure 2: Layout of Plan [2] 


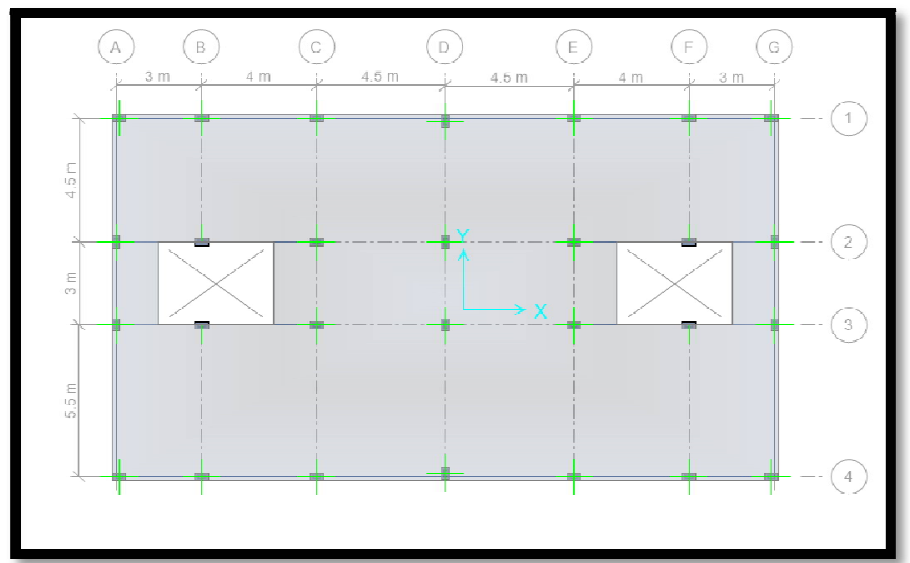

Figure 3: Model-1 Fat slab

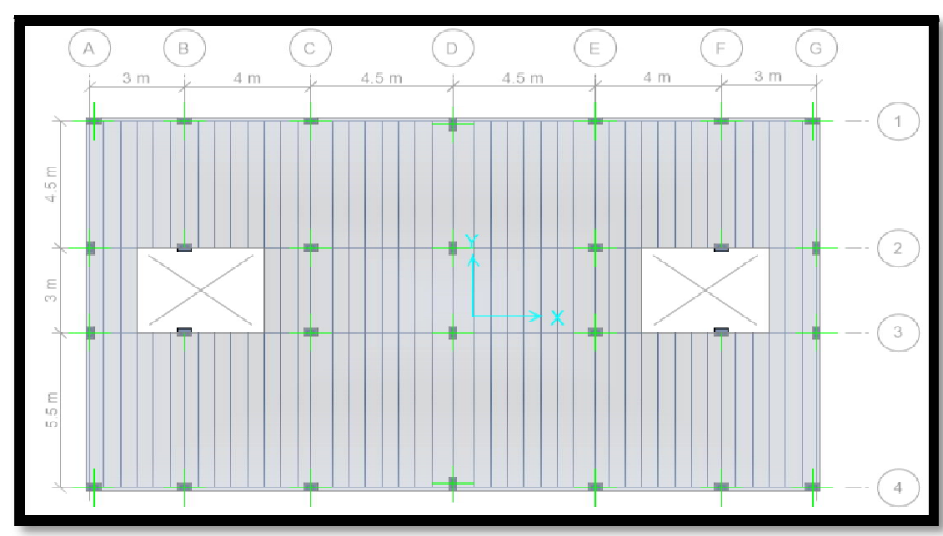

Figure 4: Model-1 Hollow Block Slab

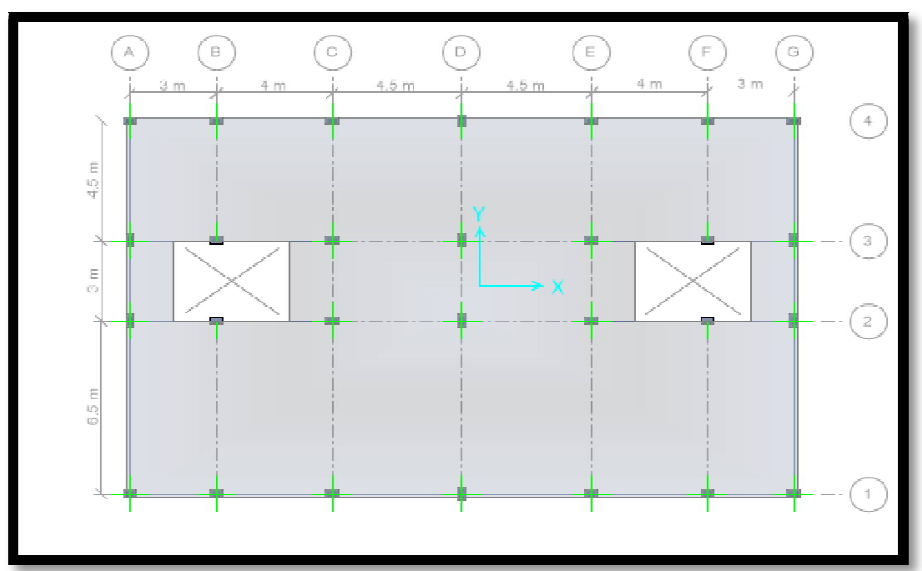

Figure 5: Model-2 Flat Slab



Figure 6: Model-2 Hollow Block Slab 


\subsection{Analysis and Design}

Structural design software (Safe) was used for the analysis and design of both floor systems. The design was based on the finite element method of Analysis. The code used for the design is the BS8110, BS6399, and other relevant codes of practice. The design loadings considered were both dead and imposed loads. The material and geometric properties of the single-storey building are presented in Tables 1,2 , and 3.

\begin{tabular}{|c|c|}
\hline Standards & BS 8110 : 1997 \\
\hline Material name & Concrete \\
\hline Type of material & Isotropic \\
\hline Mass per unit volume & $2.4 \mathrm{KN} / \mathrm{m}^{3}$ \\
\hline Modulus of elasticity & $22.454 \mathrm{KN} / \mathrm{mm}^{2}$ \\
\hline Poisson ratio & 0.2 \\
\hline Grade of concrete & $25 \mathrm{~N} / \mathrm{mm}^{2}$ \\
\hline Grade of steel & $460 \mathrm{~N} / \mathrm{mm}^{2}$ \\
$\mathrm{~F}_{\mathrm{y}}$ & $250 \mathrm{~N} / \mathrm{mm}^{2}$ \\
$\mathrm{~F}_{\mathrm{ys}}$ & \\
\hline
\end{tabular}

Table 1: Description of Material Properties

The loading condition in the building is defined as follows; the dead load is considered:

- $\quad$ Own weight from the slab is calculated based on the variable dimensions taking the unit weight of concrete is $24 \mathrm{kN} / \mathrm{m}^{3}$.

- $\quad[$ Finishes + partitions $] l o a d s=5.7 \mathrm{kN} / \mathrm{m}^{2}$.

- $\quad$ Live load $=1.5 \mathrm{kN} / \mathrm{m}^{2}$

- $\quad$ Load combinations $=1.4 \mathrm{dead}+1.6$ live $(1.4 \mathrm{Gk}+1.6 \mathrm{QK})$

\begin{tabular}{|c|c|}
\hline Structure Type & Flat Slab \\
\hline Structure Function & Residential building floor \\
\hline 1-Length in X-direction & $23 \mathrm{~m}$ \\
\hline 2-Length in Y-direction & $13 \mathrm{~m}$ \\
\hline 3-Floor to floor height & $3 \mathrm{~m}$ \\
\hline 4-Number of stories & 1 \\
\hline 5-Total height of building & $3 \mathrm{~m}$ \\
\hline Slab thickness & $200 \mathrm{~mm}$ \\
\hline 7-Size of the column & $250 \mathrm{~mm} \times 450 \mathrm{~mm}$ \\
\hline 8-Grade of concrete & $25 \mathrm{~N} / \mathrm{mm}^{2}$ \\
\hline 9-cover & $25 \mathrm{~mm}$ \\
\hline
\end{tabular}

Table 2: Physical Properties of Single Story Flat Slab Building

\begin{tabular}{|c|c|}
\hline 1- Length in X-direction & $23 \mathrm{~m}$ \\
\hline 2-Length in Y-direction & $13 \mathrm{~m}$ \\
\hline 3-Floor to floor height & $3 \mathrm{~m}$ \\
\hline 4-Number of stories & 1 \\
\hline 5-Total height of building & $9 \mathrm{~m}$ \\
\hline 6-Hidden beam & $260 \mathrm{~mm} \times 600 \mathrm{~mm}$ \\
Main hidden beam & $260 \mathrm{~mm} \times 400 \mathrm{~mm}$ \\
Outer hidden beam & $260 \mathrm{~mm} \times 400 \mathrm{~mm}$ \\
Enterer hidden beam & $260 \mathrm{~mm} \times 125 \mathrm{~mm}$ \\
\hline Ribs & $70 \mathrm{~mm}$ \\
\hline 7-Slab thickness & $250 \mathrm{~mm} \times 450 \mathrm{~mm}$ \\
\hline 8-Size of the column & $25 \mathrm{~N} / \mathrm{mm}^{2}$ \\
\hline 9-Grade of concrete & $25 \mathrm{~mm}$ \\
\hline 10-cover & $0.5 \mathrm{KN} / \mathrm{m}^{2}$ \\
\hline 11- weight of block & $6 \mathrm{KN} / \mathrm{m}^{2}$ \\
\hline 12-density of block & $\mathrm{s} / \mathrm{ab}$ \\
\hline
\end{tabular}

Table 3: Physical Properties of Single Story Hollow Block Slab 


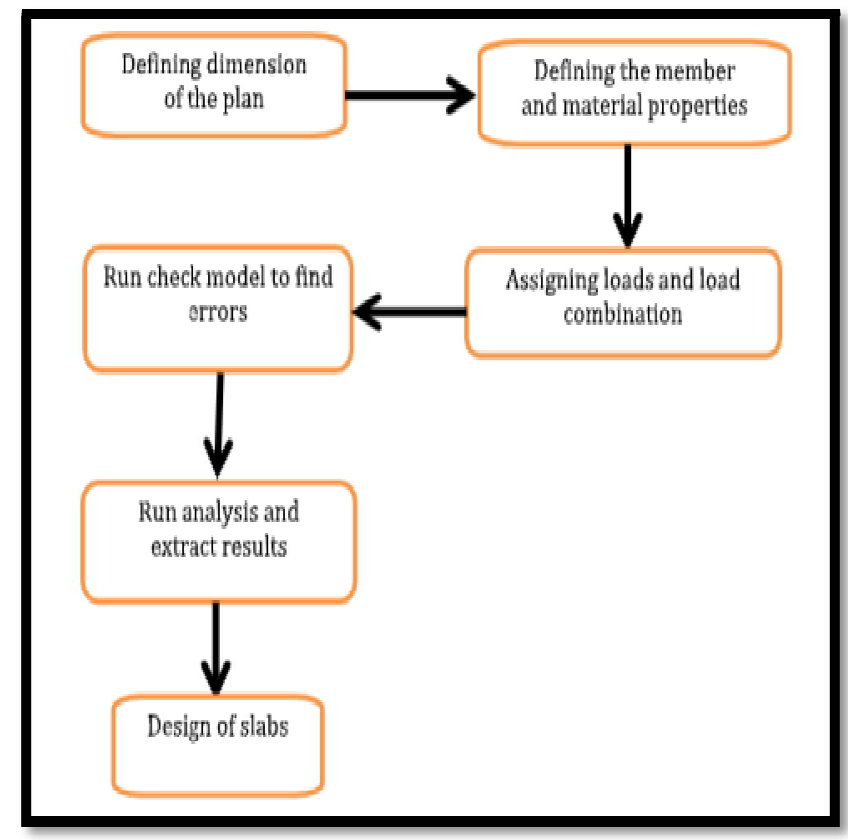

Figure 7: Flow Chart Shows Steps That Followed in Safe Program

\section{Results and Discussion}

From Table 4, the steel reinforcement of the flat slab for $50 \mathrm{~m}^{2}$ is (1.67 ton) and on the other hand in the hollow block slab with the same area is (1.095 ton), with an increase in the steel reinforcement quantity for flat slab by $(0.575$ ton). In Addition, The concrete of the flat slab for $50 \mathrm{~m}^{2}$ is $\left(11 \mathrm{~m}^{3}\right)$ but the concrete in the hollow block is $(8.1 \mathrm{~m})^{3}$. So, the quantity of concrete for the flat slab increased by $26.36 \%$ than the hollow block slab. Furthermore, the total cost of the flat slab for $50 \mathrm{~m}^{2}$ is $(299,800 \mathrm{SDG})$ but the hollow block slab is $(235,220 \mathrm{SDG})$, with an increase in the total cost of the flat slab by $(64,580$ SDG).

\begin{tabular}{|c|c|c|c|c|c|c|}
\hline \multicolumn{7}{|c|}{ Concrete $=9,500 \mathrm{SDG} / \mathrm{m}^{3}$, Steel $=90,000 \mathrm{SDG} /$ ton, Block $=30 \mathrm{SDG} /$ unit } \\
\hline \multicolumn{7}{|c|}{ Flat slab with $0.22 \mathrm{~m}$ thickness } \\
\hline Area $\left(\mathrm{m}^{2}\right)$ & 50 & 100 & 150 & 200 & 250 & 300 \\
\hline Concrete $\left(\mathrm{m}^{3}\right)$ & 11 & 22 & 33 & 44 & 55 & 66 \\
\hline Steel (Ton) & 1.67 & 3.34 & 5.01 & 6.68 & 8.35 & 10.02 \\
\hline Cost of construction (SDG)/Area & 45000 & 90000 & 135000 & 180000 & 225000 & 270000 \\
\hline $\begin{array}{l}\text { Cost of materials (steel + } \\
\text { concrete) } /(\text { SDG) }\end{array}$ & 254800 & 509600 & 764400 & 1019200 & 1274000 & 1528800 \\
\hline Total (SDG) & 299800 & 599600 & 899400 & 1199200 & 1499000 & 1798800 \\
\hline \multicolumn{7}{|c|}{ Hollow block slab with $0.26 \mathrm{~m}$ thickness } \\
\hline Area $\left(\mathrm{m}^{2}\right)$ & 50 & 100 & 150 & 200 & 250 & 300 \\
\hline Concrete $\left(\mathrm{m}^{3}\right)$ & 8.1 & 16.2 & 24.3 & 32.4 & 40.5 & 48.6 \\
\hline Steel reinforcement (Ton) & 1.095 & 2.19 & 3.285 & 4.38 & 5.475 & 6.57 \\
\hline Block (unit) & 324 & 648 & 972 & 1298 & 1620 & 1944 \\
\hline Cost of construction (SDG)/Area & 50000 & 100000 & 150000 & 200000 & 250000 & 300000 \\
\hline $\begin{array}{l}\text { Cost of materials (steel } \\
\text { reinforcement+concrete+block) } /(\mathrm{SDG})\end{array}$ & 185220 & 370440 & 555660 & 740880 & 926100 & 1111320 \\
\hline Total (SDG) & 235220 & 470440 & 705660 & 940880 & 1176100 & 1411320 \\
\hline $\begin{array}{l}\text { Percentage Diff. ( materials for } \\
\text { hollow slab against flat slab ) }\end{array}$ & $27.31 \%$ & $27.31 \%$ & $27.31 \%$ & $27.31 \%$ & $27.31 \%$ & $27.31 \%$ \\
\hline $\begin{array}{l}\text { Increase ratio(Cost of construction } \\
\text { for hollow slab against flat slab ) }\end{array}$ & $10 \%$ & $10 \%$ & $10 \%$ & $10 \%$ & $10 \%$ & $10 \%$ \\
\hline Percentage Diff. (Total cost) & $21.54 \%$ & $21.54 \%$ & $21.54 \%$ & $21.54 \%$ & $21.54 \%$ & $21.54 \%$ \\
\hline
\end{tabular}

Table 4: Cost Effectiveness of Hollow Block and Flat Slab Model-1 


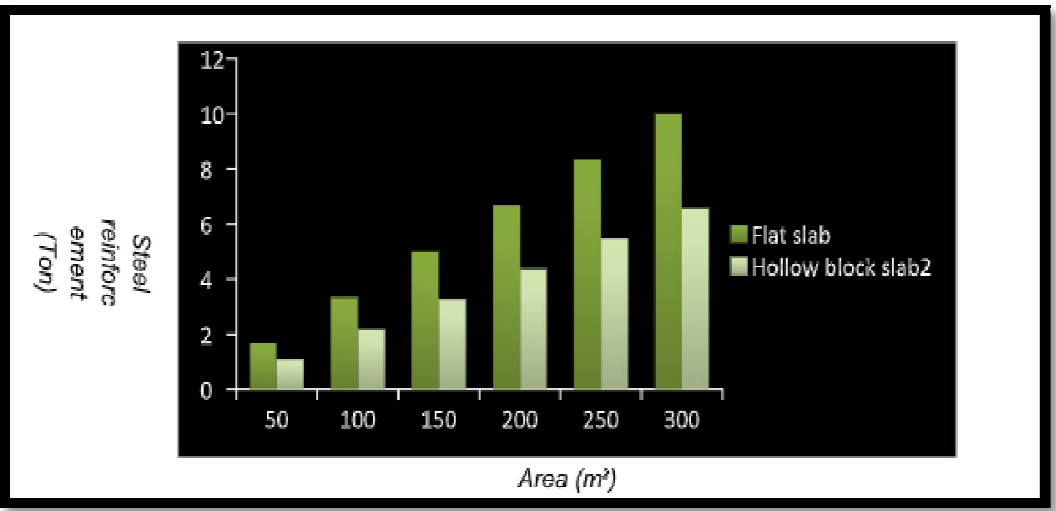

Figure 8: Comparison of the Steel Reinforcement Quantity (Ton) in the Two Slabs

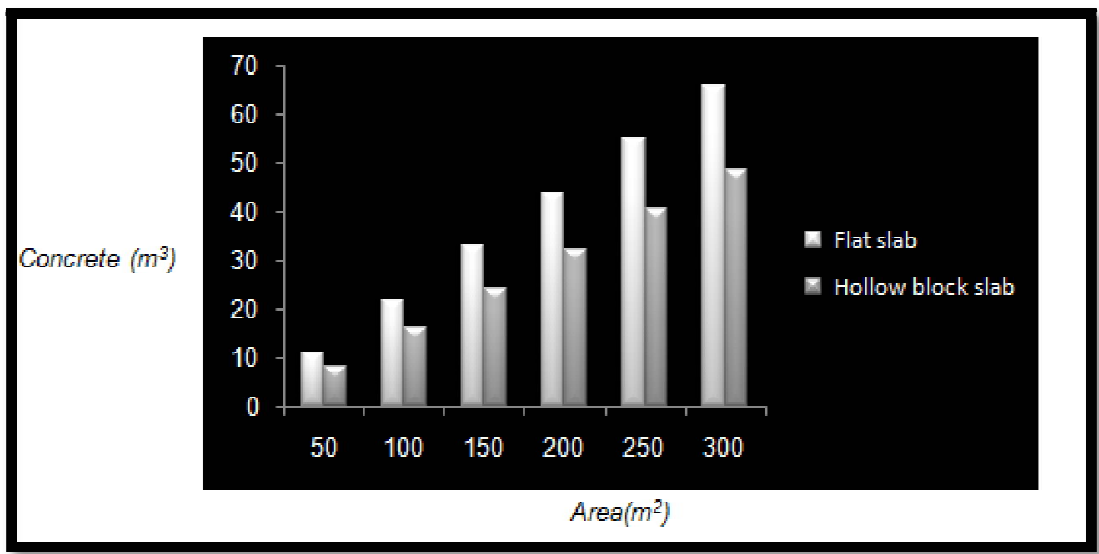

Figure 9: Comparison Of Concrete Quantity (M³) In The Two Slabs.

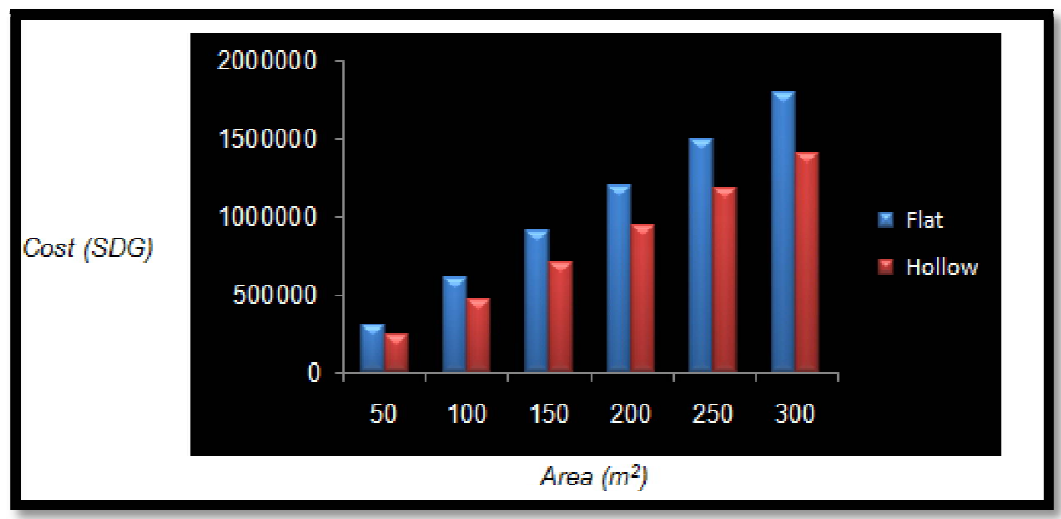

Figure 10: Comparison of the Total Cost (SDG) in the Two Slabs

As shown in Table 5 the steel reinforcement of the flat slab for $50 \mathrm{~m}^{2}$ is (1.8 ton) and on the other hand in the hollow block is ( 1.045 ton) ), with an increase in the steel reinforcement of the flat slab by ( 0.755 ton). In Addition, the concrete quantity of the flat slab for $50 \mathrm{~m}^{2}$ is $\left(12.5 \mathrm{~m}^{3}\right)$ but the concrete in the hollow block is $\left(8.1 \mathrm{~m}^{3}\right)$ ). So, the quantity of concrete for the flat slab increased by $35.2 \%$ than the hollow block slab. Moreover, the total cost of the flat slab for $50 \mathrm{~m}^{2}$ is $(325,750 \mathrm{SDG})$ but the hollow block slab is $(230,720 \mathrm{SDG})$, with an increase in the total cost of the flat slab by $(95,030$ SDG). 


\begin{tabular}{|c|c|c|c|c|c|c|c|}
\hline \multicolumn{8}{|c|}{ Concrete $=9,500$ SDG $/ \mathrm{m}^{3}$, Steel $=90,000$ SDG $/$ ton, Block $=30$ SDG $/$ unit } \\
\hline \multicolumn{8}{|c|}{ Flat slab with $0.25 \mathrm{~m}$ thickness } \\
\hline Area $\left(\mathrm{m}^{2}\right)$ & 50 & 100 & 150 & 200 & 250 & 300 & 350 \\
\hline Concrete $\left(\mathrm{m}^{3}\right)$ & 12.5 & 25 & 37.5 & 50 & 62.5 & 75 & 87.5 \\
\hline Steel (Tone) & 1.8 & 3.6 & 5.4 & 7.2 & 9 & 10.8 & 12.6 \\
\hline $\begin{array}{l}\text { Cost of construction } \\
\text { (SDG)/Area }\end{array}$ & 45000 & 90000 & 135000 & 180000 & 225000 & 270000 & 315000 \\
\hline $\begin{array}{c}\text { Cost of materials (steel + } \\
\text { concrete) } /(\text { SDG) }\end{array}$ & 280750 & 561500 & 842250 & 1123000 & 1403750 & 1684500 & 1965250 \\
\hline Total (SDG) & 325750 & 651500 & 977250 & 1303000 & 1628750 & 1954500 & 2280250 \\
\hline \multicolumn{8}{|c|}{ Hollow block slab with $0.26 \mathrm{~m}$ thickness } \\
\hline Area $\left(m^{2}\right)$ & 50 & 100 & 150 & 200 & 250 & 300 & 350 \\
\hline Concrete $\left(\mathrm{m}^{3}\right)$ & 8.1 & 16.2 & 24.3 & 32.4 & 40.5 & 48.6 & 56.7 \\
\hline Steel (Ton) & 1.045 & 2.09 & 3.135 & 4.18 & 5.225 & 6.27 & 7.315 \\
\hline Block (unit) & 324 & 648 & 972 & 1298 & 1620 & 1944 & 2268 \\
\hline $\begin{array}{l}\text { Cost of construction } \\
\text { (SDG)/Area }\end{array}$ & 50000 & 100000 & 150000 & 200000 & 250000 & 300000 & 350000 \\
\hline $\begin{array}{l}\text { Cost of materials (steel } \\
\text { reinforcement }+ \\
\text { concrete+block)/(SDG) }\end{array}$ & 180720 & 361440 & 542160 & 722880 & 903600 & 1084320 & 1265040 \\
\hline Total (SDG) & 230720 & 461440 & 692160 & 922880 & 1153600 & 1384320 & 1615040 \\
\hline $\begin{array}{c}\text { Percentage Diff. } \\
\text { (materials for hollow slab } \\
\text { against flat slab ) }\end{array}$ & $35.63 \%$ & $35.63 \%$ & $35.63 \%$ & $35.63 \%$ & $35.63 \%$ & $35.63 \%$ & $35.63 \%$ \\
\hline $\begin{array}{l}\text { Increase ratio(Cost of } \\
\text { construction for hollow } \\
\text { slab against flat slab) }\end{array}$ & $10 \%$ & $10 \%$ & $10 \%$ & $10 \%$ & $10 \%$ & $10 \%$ & $10 \%$ \\
\hline Percentage (total cost) & $29.17 \%$ & $29.17 \%$ & $29.17 \%$ & $29.17 \%$ & $29.17 \%$ & $29.17 \%$ & $29.17 \%$ \\
\hline
\end{tabular}

Table 5: Cost Effectiveness of Hollow Block and Flat Slab Model-2

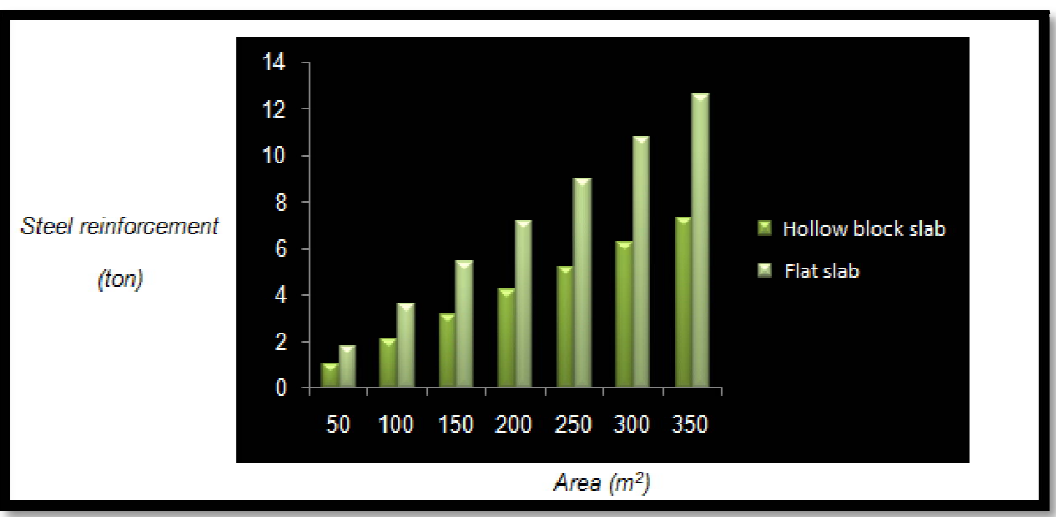

Figure 11: Comparison of the Steel Reinforcement Quantity (Ton) in the Two Slabs

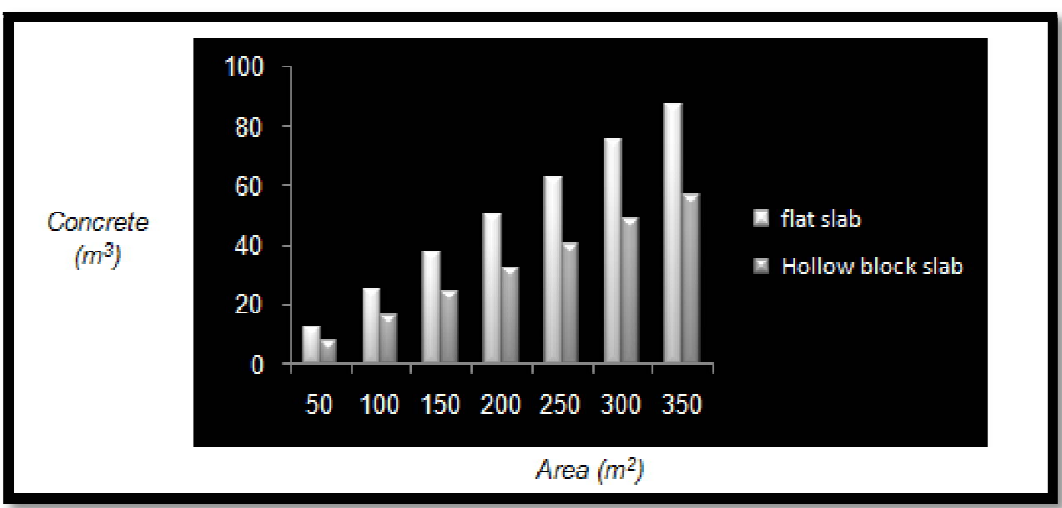

Figure 12: Comparison of the Concrete Quantity $\left(M^{3}\right)$ in the Two Slabs 


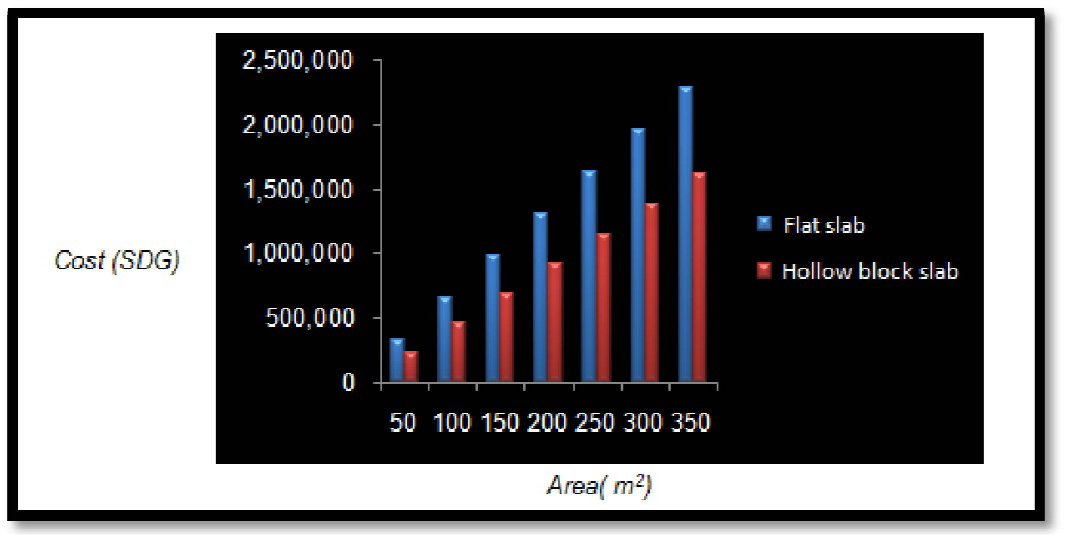

Figure 13: Comparison of the Total Cost (SDG) in the Two Slabs

Finally, Table 6 shows the comparative study between flat and hollow block slabs through model 1\&2

\begin{tabular}{|c|c|c|}
\hline Description & $\begin{array}{c}\text { Flat Slab and Hollow Block } \\
\text { Slab Model 1 }\end{array}$ & $\begin{array}{c}\text { Flat Slab and Hollow Block Slab } \\
\text { Model 2 }\end{array}$ \\
\hline $\begin{array}{c}\text { The increase in the steel } \\
\text { reinforcement for flat slab }\end{array}$ & 0.575 ton & 0.755 ton \\
\hline $\begin{array}{c}\text { The increase in the concrete } \\
\text { for flat slab }\end{array}$ & $2.9 \mathrm{~m}^{3}$ & $4.4 \mathrm{~m}^{3}$ \\
\hline $\begin{array}{c}\text { The increase in the total cost } \\
\text { for flat slab }\end{array}$ & 64,580 SDG & $95,030 \mathrm{SDG}$ \\
\hline
\end{tabular}

Table 6: Comparison between the Two Models [1\&2]

\section{Conclusion}

In this paper, a comparative study is carried out between hollow block and flat slab using Safe program based on BS 8110-1997. The results depict that the analysis of hollow block slab in model 1 and model 2 have decreased the total cost by $21.54 \%, 29.17 \%$ respectively compared to that of flat slab models. Furthermore, we can conclude that when the span is longer than $7 \mathrm{~m}$ the difference in the total cost between hollow block and flat slab is increased due to the increase in the thickness of flat slab. Hence, the hollow block slab is suitable and economical. Moreover, both Hollow and flat slabs systems are very simple to construct and efficient in that require to minimize the building height. However, Reinforced concrete of hollow block slab is inherently fire resistant, and no additional cost for fireproofing that required to meet required ratings. Further, there is no punching shear in hollow block while high in the flat slab whenever the span is long.

\section{Recommendation}

For particulars:

- In the residential building that has lightweight using hollow block slab.

- Use these systems in another country like Yemen with the same volume of hollow block.

- How to convince the owner in Sudan for choice hollow block slab and explain for him the advantages.

- Check punching shear manually because the program does not calculate reinforcement steel

For future studies:

- Study the analysis and design of hollow block and flat slab system building under the influence of earthquakes.

- Study the analysis and design of hollow block and flat slab system building in other countries.

- Study the analysis and design of hollow block slab only under variable parameters.

- Study the analysis and design of flat slab only under variable parameters.

- Using cork as hollow blocks in a dropped ceiling.

- Study the analysis and design of hollow block and flat slab system building using Robot program according to British code (BS 8110-1997).

- Study the analysis and design of hollow block and flat slab system in the commercial building.

\section{References}

i. Arman, Ibrahim Mohammad. 'Analysis of two-way ribbed and waffle slabs with hidden beams.' International Journal of Civil \& Structural Engineering 4.3 (2014): 342-352.

ii. $\quad$ Dovich, Laurel M., and James K. Wight. 'Effective slab width model for seismic analysis of flat slab frames.' ACI Structural Journal 102.6 (2005): 868.

iii. Al-Azzawi, Adel A., and J. Abbas. 'Behavior of one way reinforced concrete slabs with styropor blocks.' Advances in Concrete Construction 5.5 (2017): 451.

iv. Bikçe,Murat, and Bünyamin Akyol.'

Tasarlanmışgerçekyapılardaasmolen/plakdöşemedönüşümününyapımaliyetineetkisi.' (2017). 
v. Al-Azzawi, Adel A., and Sadeq A. Abed. 'Investigation of the behavior of reinforced concrete hollow-core thick slabs.'Comput. Concrete 19.5 (2017): 567-577.

vi. Bhatia, Navjot Kaur, and Tushar Golait. 'Studying the Response of Flat Slabs \& Grid Slabs Systems in Conventional RCC Buildings.' International Journal of Trend in Research and Development 3.3 (2016): 334337.

vii. Khan, Salman I., and Ashok R. Mundhada. 'Comparative study of seismic performance of multistoried Rcc buildings with flat slab and grid slab: a review.' International. Journal of structural and Civil Engineering research 4.1 (2015): 75-80p.

viii. Makode, Ravi Kumar, Saleem Akhtar, and Geeta Batham. 'Dynamic analysis of multistory rcc building frame with flat slab and grid slab.' Al Int. Journal of Engineering Research and Applications 4.2 (2014): 416-420.

ix. Allawi, N. 'Behavior and strength of one way voided reinforced concrete slabs.' Proceedings of the International Conference for Engineering Science, University of Al Mustansiriya, Baghdad, Iraq. 2014.

x. Rahman, Vakas K., and A. R. Mundhada. 'Comparative study of rcc and prestressed concrete flat Slabs.' International Journal of Modern Engineering Research 3 (2013).

xi. Alzanen, A.H.M 'Comparison between hollow block slabs and flat slabs in design and cost', Sudan University of Science and Technology., 2012.

xii. Sathawane, Amit A., and R. S. Deotale. 'Analysis and design of flat slab and grid slab and their Cost comparison.' International Journal of Engineering Research and Applications 1.3 (2011): 837-848.

xiii. Ghoneim, Mashour, \& El-Mihilmy, Mahmoud 'Design of Reinforced Concrete Structures. Cairo University (2008).

xiv. Reynolds, Charles E., James C. Steedman, and Anthony J. Threlfall. Reinforced concrete designer's handbook. CRC Press, 2007.

xv. Kai, Cheung Yau, and Olgierd Cecil Zienkiewicz. 'The finite element method in structural and continuum mechanics, numerical solution of problems in structural and continuum mechanics.' (1967).

xvi. Tayseer Ismail Hasb ALLA 'Finite Element Study of the Use of Reinforced Concrete Grids in Large Spans Slabs ,Case Study: Eltadamon Tower (2018) 